\title{
USTAWA \\ Z DNIA 14 MARCA 1996 R. O OCHRONIE PRAW DZIECKA REPUBLIKI LITEWSKIEJ
}

Zmiana ustawy z dnia 01.07.2018 r.

\section{Tytuł I}

\section{PRZEPISY WSTĘPNE}

\section{Artykuł 1. Przedmiot Ustawy}

1. Przedmiotem tej ustawy jest - zapewnienie obrony i ochrony praw dziecka, wzmocnienie obowiązków i możliwości opieki nad dzieckiem, rodzicem i innymi przedstawicielami dziecka, aby zapewnić ochronę interesów dziecka, ustalić podstawy pomocy dla dziecka i rodziny lub innych przedstawicieli dziecka, biorąc pod uwagę postanowienia Konstytucji Republiki Litewskiej, Konwencji Narodów Zjednoczonych o Prawach Dziecka i Deklaracji Praw Dziecka, określić mechanizmy obrony i ochrony praw dziecka, instytucji ochrony praw dziecka, podstawę prawną ich działalności oraz ogólne przepisy dotyczące odpowiedzialności za naruszenia praw dziecka.

2. Przepisy tej ustawy są zgodne z aktami prawnymi Unii Europejskiej (Dyrektywa Parlamentu Europejskiego i Rady 2011/93/UE z dnia 13 grudnia 2011 r. w sprawie zwalczania niegodziwego traktowania w celach seksualnych i wykorzystywania seksualnego dzieci oraz pornografii dziecięcej, zastępująca decyzję ramową Rady 2004/68/WSiSW).

\section{Artykuł 2. Podstawowe definicje ustawowe}

1. Przypadek - kompleksowa potrzeba pomocy dziecku i (lub) jego przedstawicielom oraz możliwe naruszenie praw dziecka i (lub) poziom zagrożenia dla dziecka określony zgodnie z ustawą.

2. Zarządzanie przypadkiem - organizowanie i udzielanie kompleksowej pomocy dziecku i jego przedstawicielom, koordynowane przez kie- 
rowników prowadzących sprawę w celu udzielenia pomocy i pokonania trudności społecznych, których skuteczne rozwiązanie stworzy warunki wstępne dla zapobieżenia możliwym naruszeniom praw dziecka i umożliwi dziecku samodzielne zagwarantowanie i zapewnienie jego praw oraz uzasadnionych interesów.

3. Kierownik - pracownik socjalny, który koordynuje proces zarządzania przypadkiem, mianowany przez kierownika miejskiej instytucji opieki społecznej lub innej instytucji, do której przełożony lub upoważniona przez samorząd osoba przyznała władzę socjalnym rodzinom w zakresie świadczenia usług.

4. Usługi społecznościowe - różne formy i typy gmin społecznych, zdrowotnych, edukacyjnych, psychologicznych, prawnych, kulturalnych i innych, państwowych, organizacji pozarządowych, które są świadczone we wspólnocie miejsca zamieszkania odbiorcy, umożliwiające rodzinie samodzielne rozwiązywanie problemów, otrzymanie pomocy, która jest odpowiednia do indywidualnych potrzeb dziecka lub rodziny, umożliwiające dziecku dorastanie $\mathrm{w}$ środowisku rodzinnym i promowanie niezależności usługobiorców, ich uczestnictwa w społeczności i integracji społecznej.

5. Kara fizyczna - kara wychowawcza, gdy czynność fizyczna jest używana do wywoływania fizycznego bólu i może spowodować niską szkodliwość lub spowodować fizyczne znęcanie się nad dzieckiem lub upokorzyć jego honor i/lub godność. Zwykłe kary i inne sankcje wobec nieletnich stosowane przez państwo nie są uważane za karę fizyczną.

6. Kompleksowa pomoc - zestawienie środków społecznych, zdrowotnych, edukacyjnych, psychologicznych i innych środków pomocy, które umożliwiają przedstawicielom prawnym dziecka zapewnienie dziecku bezpieczeństwa, odpowiedniego funkcjonowania rodziny i niezbędnego dobrostanu dziecka.

7. Ekipa mobilna - grupa specjalistów, która pilnie zapewnia i organizuje indywidualne lub grupowe medyczne, psychologiczne, socjalne, prawne wsparcie dla dziecka i rodziny, znajdującej się w kryzysie.

8. Plan pomocy - dla dziecka i jego rodziców lub innych przedstawicieli dziecka i osób mieszkających z dzieckiem - niezbędne środki z zakresu usług społecznych, zdrowotnych, edukacyjnych, psychologicznych i innych oraz pomocy społecznej, mającej na celu zapewnienie odpowiedniej ochrony praw dziecka przy ustalaniu osoby organizującej i zapewniającej takie środki, usługi i wsparcie, biorąc pod uwagę indywidualne potrzeby dziecka, rodziców lub innych przedstawicieli dziecka. 
9. Przemoc nad dzieckiem - bezpośrednie lub pośrednie działanie lub zaniechanie działań fizycznych, psychicznych, seksualnych nad dzieckiem, jeśli dziecko zmarło lub zagrożone jest jego życie oraz zdrowie, normalny rozwój, honor lub jego godność. Zaniedbanie dziecka jest również uważane za przemoc wobec dziecka.

10. Dziecko - osoba poniżej 18 roku życia.

11. Interes dziecka - zdrowe i bezpieczne środowisko oraz warunki, które zaspokajają indywidualne potrzeby dziecka, odpowiadające wiekowi, rozwojowi, zdolności i dojrzałości dziecka oraz zapewniające prawidłowy rozwój i wychowanie dziecka.

12. Niebezpieczne środowisko dla dziecka - przestrzeń życiowa lub inne środowisko dziecka, w którym żyje dziecko, zdrowie lub normalny rozwój, które są zagrożone z powodu zaniedbania, przemocy lub innych społecznych czynników ryzyka.

\section{Artykuł 3. Przemoc wobec dziecka}

Formy przemocy wobec dziecka:

a) Przemoc fizyczna jest umyślnym działaniem fizycznym lub działaniem przeciwko dziecku, a także karą fizyczną, jeśli dziecko w ten sposób zmarło, jego zdrowie lub normalny rozwój zostały zakłócone, spowodowało to ból lub zagrożenie życia, zdrowia lub normalnego rozwoju dziecka lub honoru dziecka i/lub godności;

b) przemoc psychiczna jest celowym systematycznym naruszaniem prawa dziecka do tożsamości, upokorzenia dziecka, znęcania się, zastraszania, koniecznego dla normalnego rozwoju dziecka, propagowania zachowania aspołecznego lub innego zachowania (działania lub zaniechania) kontaktu niefizycznego, który spowodował śmierć dziecka, jego zdrowia lub rozwój lub zagrożenie życia, zdrowia, normalnego rozwoju dziecka lub honoru dziecka i/lub godności dziecka;

c) przemoc seksualna - celowe przestępstwa określone w rozdziale XXI Kodeksu karnego Republiki Litewskiej, jak również czerpanie zysku z dziecięcej prostytucji, zaangażowanie dziecka w prostytucję lub udział w wydarzeniu pornograficznym, wyświetlanie pornografii dziecięcej, wykorzystywanie dziecka do pornografii lub posiadanie treści pornograficznych przedstawiających dziecko lub osobę jako dziecko lub włączenie dziecka w niewolnicze życie seksualne i inne formy niegodziwego traktowania dzieci w celach seksualnych; 
d) zaniedbanie - rodziców lub innych przedstawicieli dziecka w zakresie obowiązków opiekuńczych nad dzieckiem lub zaniedbanie potrzeb fizycznych, emocjonalnych i społecznych niezbędnych dla dziecka, które spowodowały śmierć dziecka, zakłócenie jego zdrowia lub normalnego rozwoju lub zagroziły jego życiu lub zdrowiu.

\section{Artykuł 4. Zasady ochrony prawa i wolności dziecka}

Rodzice, inni przedstawiciele dziecka, instytucje i organy państwowe, organizacje pozarządowe, inne osoby fizyczne i prawne muszą przestrzegać następujących zasad:

a) priorytet interesu dziecka - podejmowanie decyzji lub podejmowanie jakichkolwiek działań związanych z dzieckiem wynikających z najlepszego interesu dziecka. Zasada interesu dziecka ma zastosowanie w zależności od sytuacji danej osoby, aby ustalić, co jest najkorzystniejsze dla dziecka w najbliższej przyszłości i w przyszłości, wskazując, że interesy dziecka zostały przeanalizowane i uwzględnione w pierwszej kolejności. Dziecko musi otrzymać ochronę niezbędną dla jego/jej dobrego samopoczucia, wykorzystując wszystkie możliwe skoordynowane kompleksowe wsparcie;

b) praworządność - ochrona praw dziecka zapewniona jest zgodnie z Konstytucją Republiki Litewskiej, Konwencją Narodów Zjednoczonych o Prawach Dziecka, innymi ratyfikowanymi traktatami międzynarodowymi, prawem Republiki Litewskiej;

c) wysłuchanie opinii dziecka i zapewnienie udziału dziecka - dziecko, które jest w stanie sformułować swoje poglądy, musi być wysłuchane we wszystkich sprawach związanych z nim, biorąc pod uwagę jego wiek i dojrzałość i musi być brane pod uwagę, jeżeli nie jest to sprzeczne z interesem dziecka;

d) niedyskryminacja - każde dziecko ma równe prawa z innymi dziećmi i nie może być dyskryminowane ze względu na płeć, rasę, narodowość, język, pochodzenie, status społeczny, przekonania lub wierzenia, wiek, stan zdrowia, religię, pochodzenie etniczne, zależność lub inne okoliczności. Każdemu dziecku, bez żadnej dyskryminacji, gwarantuje się prawa i wolności określone w Konstytucji, Konwencji Narodów Zjednoczonych o Prawach Dziecka, Konwencji Narodów Zjednoczonych o Prawach Osób Niepełnosprawnych, Deklaracji Praw Dziecka w sprawie Organizacji Narodów Zjednoczonych; 
e) dostosowywanie - podejmowanie decyzji dotyczących dziecka uwzględniających jego wiek, dojrzałość, jego cechy psychiczne i fizyczne, potrzeby, otoczenie społeczne i inne ważne cechy;

f) zapewnienie zdrowego rozwoju dziecka - każde dziecko, zarówno przed jak i po urodzeniu, musi mieć zapewnioną możliwość zdrowego i normalnego rozwoju;

g) pomocniczość - realizacja i ochrona praw dziecka są przede wszystkim zapewniane przez rodziców dziecka i innych przedstawicieli dziecka, a państwo zapewnia im pomoc, jeżeli przedstawiciele dzieci nie są w stanie zapewnić warunków niezbędnych dla dobra dziecka;

h) współpraca - państwowe instytucje i organy, służące pomocą $\mathrm{w}$ wykonywaniu funkcji związanych z ochroną praw dziecka, za pośrednictwem organizacji pozarządowych konsekwentnie współpracują z przedstawicielami ustawowymi dziecka i między sobą oraz dostarczają sobie nawzajem niezbędnych informacji i innej pomocy;

i) dostępność - jeżeli dziecko potrzebuje pomocy, usługi świadczone są jak najbliżej miejsca zamieszkania dziecka oraz w taki sposób, aby zaspokoić potrzeby dziecka i jego rodziców lub innych przedstawicieli oraz ich uzasadniony interes;

j) nienaruszalność życia prywatnego - realizacja ochrony praw dziecka oraz udzielanie wsparcia i pomocy dziecku, jego rodzicom lub innym przedstawicielom dziecka zapewniana jest w ten sposób, że rodzina nie może doświadczać bezprawnej, niepotrzebnej i nieproporcjonalnej ingerencji w życie prywatne, a informacje o prywatnym życiu rodziny nie mogą zostać ujawnione stronom trzecim;

k) uczestnictwo rodziców dziecka lub innych przedstawicieli prawnych - podejmowanie decyzji dotyczących dziecka zapewnia się przez uwzględnienie opinii jego rodziców lub innych przedstawicieli dziecka, z wyjątkiem przypadków, jeśli jest to sprzeczne z interesem dziecka;

l) ojcostwo i macierzyństwo - przy realizacji ochrony praw dziecka uwzględnia naturalna potrzeba posiadania rodziców;

ł) jedność - wszystkie dzieci, które potrzebują i/lub które ubiegają się o pomoc, podlegają kompleksowej pomocy i świadczeniom w zakresie usług społecznych i innych niezbędnych usług;

m) niestygmatyzacja - dziecko, jego rodzice lub inni przedstawiciele dziecka są chronieni przed selektywnością społeczną i negatywnym oznakowaniem, aby uniknąć jeszcze większego wykluczenia społecznego; 
n) supremacja - dziecko, zwłaszcza w przypadkach przestępczych zachowań, ma zapewnioną supremację pomocy przed środkami kryminalnymi;

o) pierwszeństwo niestacjonarnych środków przeciwko stacjonarnym - dzieci, ich rodzice lub inni przedstawiciele dziecka, którzy są ofiarami przemocy, mają oferowane środki pomocy w samopomocy i ciągłość pomocy społecznej.

\section{Artykuł 5. Ustawy i inne akty prawne określające prawa i wolności dziecka i regulujące ich ochronę}

1. W przypadku, gdy relacje z prawami i wolnościami dziecka oraz ich ochrona są regulowane innymi przepisami i regulacjami innymi niż niniejsze prawo, zastosowanie mają odpowiednie przepisy niniejszej ustawy, z wyjątkiem ratyfikowanych umów międzynarodowych, aktów prawnych Unii Europejskiej, o ile nie są sprzeczne z Konstytucją.

2. Kiedy relacje ochrony praw dziecka nie są regulowane przez te lub inne ustawy lub akty prawne, przestrzegane są zasady określone w art. 4 tej ustawy.

$[\ldots]$

\section{Tytuł III \\ DZIECKO I ŚRODOWISKO SPOŁECZNE}

\section{Artykuł 25. Przepisy ogólne dotyczące ochrony dziecka przed negatywnym otoczeniem społecznym}

1. Instytucje państwowe, rodzice dziecka lub inni przedstawiciele dziecka, inne osoby fizyczne i prawne chronią dziecko przed negatywnym wpływem otoczenia społecznego.

2. Instytucje państwowe $\mathrm{w}$ celu ochrony praw dziecka przygotowują i prowadzą programy służące realizacji praw dziecka oraz korzystają z pośrednictwa organizacji pozarządowych przeprowadzających te programy.

3. Litewskie Narodowe Radio i Telewizja na podstawie umowy z Rządem bezpłatnie przydzielają eter pokazu związany $\mathrm{z}$ zapewnieniem ochrony praw dziecka. 


\section{Artykuł 26. Przepisy ogólne dotyczące ochrony dziecka przed} substancjami psychoaktywnymi i czynnikami uzależniającymi

1. Dla wychowania dziecka ma znaczenie zakaz używania produktów tytoniowych, napojów alkoholowych, substancji odurzających, psychotropowych i innych substancji psychoaktywnych, a także, że produkty lecznicze powinny być używane wyłącznie do celów terapeutycznych.

2. Dziecko jest ochronione przed używaniem wyrobów tytoniowych, napojów alkoholowych i energetycznyh środków odurzających, substancji psychotropowych, wytwarzaniem, przetwarzaniem, nabywaniem, przechowywaniem, transportem, przekazywaniem, sprzedażą lub inną dystrybucję takich materiałów. Dziecko jest również ochronione przed udziałem w grach hazardowych i innymi czynnikami uzależniającymi.

3. Dziecko może podlegać profilaktyce, edukacji, leczeniu (w tym leczeniu uzależnień) i programom rehabilitacji, w zależności od wieku, zdrowia, rozwoju i dojrzałości.

4. Ograniczenia nie mają zastosowania, gdy lekarz przepisuje produkty lecznicze zawierające substancje odurzające i/lub psychotropowe, zgodnie z obowiązującym schematem leczenia - zgodnie z Charakterystyką Produktu Leczniczego.

\section{Artykuł 27. Ochrona dziecka przed substancjami psychoaktywnymi i odpowiedzialność za wciąganie dziecka w używanie zabronionych substancji}

1. Dziecko nie może używać, produkować, przetwarzać, kupować, magazynować, transportować, wysyłać ani dystrybuować napojów energetycznych i alkoholowych, tytoniu ani podobnych produktów (papierosów elektronicznych i pojemników do napełniania), środków odurzających lub substancji psychotropowych, produktów leczniczych (z wyjątkiem legalnych zakupów, własności) lub innych środków lub substancji zapobiegających, określonych w ustawie o kontroli niektórych substancji antydopingowych Republiki Litewskiej.

2. Zabronione jest wciąganie dziecka do pracy związanej z produkcją lub sprzedażą wyrobów tytoniowych lub napojów alkoholowych.

3. Rodzice dziecka lub inni przedstawiciele dziecka, inne osoby fizyczne lub prawne, które sprawują opiekę nad dzieckiem oraz których działalność związana jest z produkcją, przetwarzaniem, przechowywa- 
niem, transportem, wysyłką lub dystrybucją przedmiotów zabronionych lub używaniem przedmiotów zabronionych do użytku przez dziecko lub organizacją gier hazardowych, muszą postępować zgodnie z zakazami określonymi w tej ustawie.

4. Osoba, która wprowadziła dziecko w stan upojenia lub która nakłoniła dziecko do stosowania leków lub innych środków odurzających lub stosowania substancji określonych w ustawie o kontroli niektórych substancji antydopingowych do celów nieterapeutycznych, podlega odpowiedzialności prawnej.

\section{Artykuł 28. Ochrona dziecka przed negatywnym wpływem informacji publicznej}

1. Dziecko jest chronione przed negatywnym wpływem informacji publicznej, która może wpływać na jego zdrowie psychiczne lub fizyczne, rozwój fizyczny, umysłowy, duchowy lub moralny.

2. Dziecko jest chronione przed grami komputerowymi, które fizycznie i psychicznie szokują go i zagrażają jego zdrowiu i bezpieczeństwu. Zabrania się dziecku tworzenia, utrzymywania i rozpowszechniania zdjęć przedstawiających seksualne obrazy własne i innych dzieci oraz zdjęć przedstawiających zastraszanie i przemoc wobec dzieci, innych osób i zwierząt w sieciach komputerowych (w Internecie).

3. Zabronione jest pokazywanie, sprzedawanie, przekazywanie, reprodukowanie i wypożyczanie lub dystrybucja w inny sposób filmów, audio i wideo, literatury, gazet, czasopism, innych publikacji lub innych przedmiotów, które bezpośrednio promują brak szacunku dla innych osób, okrutnego zachowania, przemocy, dyskryminacji, pornografii lub innych fizycznych, umysłowych, duchowych i moralnych uszkodzeń dziecka.

4. Ochrona dziecka przed negatywnym wpływem informacji publicznych, które wpływają na jego rozwój normowana jest przez ustawę regulującą ochronę nieletnich przed niekorzystnymi informacjami publicznymi i innymi przepisami przewidującymi odpowiedzialność za działania określone w tym artykule. 


\section{Artykuł 29. Ochrona dziecka przed czynami przestępczymi i przemocą oraz odpowiedzialność za naruszenia praw dziecka}

1. Dziecko musi być chronione przed przestępstwami zawartymi w Kodeksie karnym Republiki Litewskiej.

2. Dziecko jest również chronione przed wszelkimi formami przestępstwa i wszelkimi innymi naruszeniami praw osobistych lub majątkowych dziecka, nieprzewidzianych w ust. 1 niniejszego artykułu.

3. Osoba fizyczna lub prawna, która posiada wiedzę i/lub która posiada uzasadnione informacje o dziecku, które padło ofiarą przestępstwa, o którym mowa w ust. 1 i 2 niniejszego artykułu i/lub może potrzebować pomocy, powinna powiadomić policję i/lub Państwową Służbę Ochrony Praw Dziecka, zgodnie z podziałem terytorialnym.

4. Za naruszenia praw dziecka, o których mowa w ust. 1 niniejszego artykułu, osoba ponosi odpowiedzialność zgodnie z procedurą ustanowioną w Kodeksie karnym i Kodeksie postępowania karnego. Za naruszenia praw dziecka, o których mowa w ust. 2 niniejszego artykułu, osoba ponosi odpowiedzialność, zgodnie z procedurą ustanowioną w Kodeksie wykroczeń administracyjnych, Kodeksie cywilnym i innych ustawach.

5. Dyrektorzy, pedagodzy lub inni pracownicy instytucji edukacyjnych, opieki zdrowotnej oraz innych instytucji zajmujących się nadzorem nad dzieckiem, którzy nie wypełniają swoich obowiązków lub nie podejmują działań i naruszają prawa dziecka, ponoszą odpowiedzialność zgodnie z procedurą ustanowioną w Kodeksie karnym, Kodeksie wykroczeń administracyjnych, Kodeksie cywilnym i innych przepisach prawa.

6. Dziecko, które padło ofiarą przestępstwa lub przestępstwa, o którym mowa w ust. 1 niniejszego artykułu, musi mieć zapewnioną kompleksową pomoc przez jego przedstawicieli, tak aby dziecko, jego rodzice lub inni przedstawiciele dziecka mogli przywrócić mu zdrowie po urazie fizycznym lub psychicznym. Pomoc ta musi zostać uruchomiona natychmiast i musi być udzielona do czasu, aż będzie to konieczne dla dziecka i jego przedstawicieli.

7. Dziecko może samodzielnie zwrócić się do Rzecznika Praw Obywatelskich Republiki Litewskiej, Państwowej Ochrony Praw Dziecka i Służby Adopcyjnej, zgodnie z terytorialnym podziałem, policji lub edukacji, służby zdrowia lub innej instytucji, a także dziecko w wieku 14 lat - do sądu za naruszenie jego praw. 


\section{Artykuł 30. Ograniczenia pracy osób, uznanych za winne czynów przestępczych}

1. Osoby, które zostały skazane za przestępstwo na podstawie wyroku sądowego, zgodnie z Kodeksem karnym lub inne przestępstwa związane z wykorzystywaniem seksualnym dziecka, pornografią dziecięcą lub prostytucją, niezależnie od wygaśnięcia lub unieważnienia wyroku skazującego, jeżeli minęło 25 lat od popełnienia przestępstwa, mają zakaz:

a) wykonywania pracy lub podejmowania działań wolontariackich $\mathrm{w}$ organizacji $\mathrm{w}$ zakresie ochrony praw dzieci, opieki społecznej, edukacji i sportu dla dzieci, usług zdrowotnych dla dzieci;

b) wykonywania pracy lub podejmowania działań wolontariackich w instytucjach innych niż wskazane w ust. 1 pkt 1, pod warunkiem, że ta praca lub działalność wolontariacka poprzez bezpośredni i regularny kontakt jest związana z edukacją, szkoleniem, nadzorem lub bezpieczeństwem dzieci;

c) zajmowania się indywidualnymi działaniami, pod warunkiem, że działalność ta obejmuje bezpośredni, regularny kontakt z edukacją, szkoleniem, nadzorem lub bezpieczeństwem dzieci.

2. Ograniczenia pracy ustanowione w ust. 1 niniejszego artykułu nie mają zastosowania do osób, które nie ukończyły 16 lat w momencie popełnienia przestępstwa, o którym mowa w ust. 1 niniejszego artykułu, i nie popełniły nowych przestępstw po ukończeniu 16 lat.

3. Nauczyciele podlegają dodatkowo ograniczeniom dotyczącym pracy, określonym w ustawie o edukacji.

4. Rząd lub upoważniona instytucja zatwierdza listę prac, czynności lub usług, o których mowa w punktach 1, 2, i 3 niniejszego artykułu, do których wykonywania nie są uprawnione takie osoby lub zapewnienia bezpośredniego i regularnego kontaktu z dziećmi przez osobę, która została uznana winną na podstawie wyroku skazującego, o którym mowa w ust. 1 niniejszego artykułu.

5. Pracodawca zamierzający zatrudnić taką osobę w ramach wykonywania przez nią działalności zawodowej lub angażowania się w działalność wolontariacką obejmującą bezpośredni i regularny kontakt z dziećmi $\mathrm{w}$ instytucjach, przedsiębiorstwach i organizacjach, o których mowa w ust. 1 niniejszego artykułu, lub zatrudniający do prac ujętych w wykazie, o którym mowa w ust. 4 niniejszego artykułu, może zatrudnić taką osobę do pracy lub do działań dobrowolnie tylko po otrzymaniu informa- 
cji z rejestru osób podejrzanych, oskarżonych i skazanych, że dana osoba nie została skazana za przestępstwo, o którym mowa w ust. 1 niniejszego artykułu, lub że minęło 25 lat od popełnienia takiego przestępstwa.

6. Odbiorca usług wymienionych w wykazie, o którym mowa w ust. 4, który zawiera umowę o świadczenie usług na rzecz dziecka z osobą wykonującą indywidualną działalność, musi zwrócić się do usługodawcy, a usługodawca musi złożyć zaświadczenie dotyczące danych osoby podejrzanej, oskarżonej i skazanej.

7. Administrator rejestru podejrzanych, oskarżonych i skazanych przedkłada pracodawcy lub osobie, o której mowa w ust. 5 i 6 niniejszego artykułu, dane dotyczące poszczególnych czynności, dane dotyczące podejrzanego, oskarżonego i skazanego, dotyczące osoby fizycznej pracującej lub wolontariatu, o której mowa w ust. 1 niniejszego artykułu.

8. Osoba, która wyznaczyła taką osobę, nie może przekazywać osobom trzecim informacji o osobie, zgodnie z niniejszym artykułem, z wyjątkiem przypadków ustanowionych w ustawodawstwie Republiki Litewskiej.

9. Jeżeli osoba podlegająca ograniczeniom, o których mowa w ust. 1 niniejszego artykułu, zostanie przyjęta do pracy lub będzie świadczyć usługi, o których mowa w niniejszym artykule i okaże się, że przedstawiła fałszywe lub nieistniejące informacje o sobie, umowa o świadczenie usług na rzecz dziecka zostanie rozwiązana. Osoby, które są zatrudniane do pracy lub wykonywania działań wolontariackich, bez względu na ograniczenia pracy określone w niniejszym artykule, są niezwłocznie odsuwane od kontaktów z dziećmi i zwalniane z pracy, zgodnie z procedurą ustanowioną w Kodeksie pracy Republiki Litewskiej lub ustawie o służbie państwowej Republiki Litewskiej, a umowa o wolontariacie zostaje z nimi rozwiązana. Zgodność z tymi wymogami spoczywa na pracodawcy i odbiorcy.

10. W przypadku osób, o których mowa w ust. 1, ograniczenia dotyczące pracy mające zastosowanie do okresu 25 lat, mogą zostać poddane przeglądowi po upływie tego terminu, jeżeli osoby te nie popełniły nowych przestępstw, o których mowa w ust. 1.

$[\ldots]$

tłum. Iveta Vitkuté-Zvezdinienè oprac. meryt. i tłum. Jolanta Pacian ${ }^{* *}$

\footnotetext{
Kaunas College University of Applied Sciences; e-mail: iveta.vitkute-zvezdiniene@ go.kauko.lt.

** Dr, Uniwersytet Medyczny w Lublinie; e-mail: jolapacian@gmail.com.
} 
